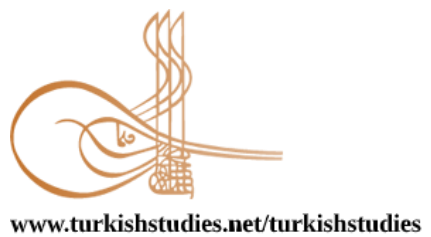

Turkish Studies

www.turkishstudies.net/turkishstudies

eISSN: $1308-2140$

TERNATIONAL

BALKAN

Sponsored by IBU

Research Article / Araştırma Makalesi

\title{
COVID-19 Salgını Sürecinde Kaygı ile Maneviyat, Psikolojik Sağlamık ve Belirsizliğe Tahammülsüzlük Arasındaki İlişkilerin İncelenmesi
}

\author{
Examination of the Relationship Between Anxiety with Spirituality, Resilience and Intolerance of \\ Uncertainty in the COVID-19 Outbreak Process
}

\author{
Figen Kasapoğlu*
}

\begin{abstract}
All over the world, and continues to spread in Turkey who COVID-19 (New Coranavirüs disease) outbreak brings together a challenge to the resilience and psychological pressure. The aim of this study is to examine the relationships between anxiety, flexibility, spirituality and intolerance in the COVID-19 outbreak process. The study group of the study consisted of 565 (373 female, 192 male) adult individuals and was selected by an appropriate sampling method. The method of the research is in a relational screening model and the data collection tools are Demographic Information Form, Common Anxiety Disorder Scale, Intolerance to Uncertainty Scale, Short Psychological Resilience Scale, and Spiritual Orientation Scale. Ethics committee approval was obtained, which was necessary to conduct the study. Relationships between variables were tested by path analysis. The proposed model has been found to have good fit indexes $(\chi 2 / \mathrm{df}(1)=.341(\mathrm{p}=.559)$, RMSEA $=.000, \mathrm{CFI}=1.00, \mathrm{GFI}=1.00, \mathrm{AGFI}=.99, \mathrm{NFI}=.99)$. The findings of the path analysis show that spirituality has an indirect and significant effect on anxiety both directly and indirectly through resilience, shows that resilience has a significant effect on anxiety both directly and indirectly through intolerance to uncertainty. In the model, anxiety is explained at the rate of $35 \%$.
\end{abstract}

Structured Abstract: Introduction. The COVID-19 was first detected on 11 March in Turkey. This epidemic causes psychological pressure and challenges resilience. Also, the World Health Organization reports that this situation causes widespread anxiety, fear, and stress in many people (www.euro.who.int).

In this study, in the context of the psychological effect of the COVID-19 outbreak on individuals in Turkey, anxiety, and intolerance to uncertainty; It is aimed to examine the defense responses of individuals against the epidemic in the context of resilience and spirituality variables. Anxiety is a fear-like emotion that people experience from time to time. The individual perceives and experiences this as an uncertain sense of anxiety and worry as if it would be bad news, a disaster (Gezgin et al., 2010). In studies conducted, anxiety is negative with resilience (Açıkgöz, 2019; Hjemdal et al., 2011; Min et al., 2013; Perişan, 2018), positive with intolerance of uncertainty (Belge, 2019; Dugas et al., 2001; Holaway et al., 2006; Sari \& Dağ, 2009; Tantan Ulu, 2019), and it was found that a negative relationship with spirituality (Nelson et al., 2009; Reutter, \& Bigatti, 2014). Glas and Poort (2007) compiled the studies on anxiety and spirituality and reported that there is a relationship between religiosity/spirituality and anxiety in various situations.

\footnotetext{
* Dr. Öğr. Üyesi, İstanbul 29 Mayıs Üniversitesi, Eğitim Fakültesi, Eğitim Bilimleri Bölümü Asst. Prof., Istanbul 29 Mayls University, Educational Faculty, Departmant of Educational Sciences ORCID 0000-0002-4070-960X

figenkasapoglu.721@gmail.com

Cite as/ Atıf: Kasapoğlu, F. (2020). COVID-19 salgını sürecinde kaygı ile maneviyat, psikolojik sağlamlık ve belirsizliğe tahammülsüzlük arasındaki ilişkilerin incelenmesi. Turkish Studies, 15(4), 599-614. https://dx.doi.org/10.7827/TurkishStudies.44284

Received/Geliş: 17 June/Haziran 2020

Accepted/Kabul: 10 August/Ağustos 2020

Copyright $(\mathrm{C}$ MDE, Turkey

Checked by plagiarism software

Published/Yayın: 30 August/Ağustos 2020

CC BY-NC 4.0
} 
When the literature is evaluated, research data are needed to develop evidence-based strategies to reduce negative psychological effects and psychological symptoms during the COVID-19 outbreak. The purpose of this study is to examine how spirituality, resilience, and intolerance of uncertainty affect anxiety during the Covid-19 outbreak.

Method. The data were collected between April and May 2020. The working group of the research consisted of 565 (373 female, 192 male) adult individuals and selected by the appropriate sampling method. The method of the research is in a relational screening model and the data collection tools are Demographic Information Form, Common Anxiety Disorder Scale, Intolerance to Uncertainty Scale, Short Psychological Resilience Scale, and Spiritual Orientation Scale. In the analysis of the data, descriptive statistics and Pearson Correlation Coefficient were applied. Relationships between variables were investigated by Path Analysis.

Results: The proposed model has been found to have good fit indexes $\left(\chi^{2} / \mathrm{df}(1)=.341(\mathrm{p}=.56)\right.$, RMSEA $=.000, \mathrm{CFI}=1.00, \mathrm{GFI}=1.00, \mathrm{AGFI}=.99, \mathrm{NFI}=.99)$. In the path analysis, spirituality $(\beta=-.08, \mathrm{p}$ $<.01, \beta=-.10, p<.01, \beta=-.17, p<.01$, respectively), resilience (respectively, $\beta=-.38, p<.01, \beta=-.11, p$ $<.01, \beta=-.49, \mathrm{p}<.01$ ) variables directly, indirectly and totally significantly and negatively effect was found. The results also showed that intolerance of uncertainty directly significantly, and positively $(\beta=.32, p<.01)$ affects anxiety. The findings of the path analysis show that spirituality has an indirect and significant effect on anxiety both directly and indirectly through resilience, shows that resilience has a significant effect on anxiety both directly and indirectly through intolerance to uncertainty. In the model, anxiety is explained at the rate of $35 \%(\mathrm{R} 2=.35)$.

Discussion: In this study, the effect of spirituality, resilience, and intolerance to ambiguity on the anxiety levels of individuals living in Istanbul in the Covid-19 pandemic was analyzed by path analysis. The result obtained is that spirituality has a significant effect on anxiety both directly and indirectly through resilience. It shows that resilience has a significant effect on anxiety both directly and indirectly through intolerance to uncertainty. Based on this finding, when the spirituality of individuals is strong during the COVID-19 outbreak period, it can be concluded that resilience levels are high and levels of tolerance to uncertainty increase, and thus anxiety levels decrease.

COVID-19 pandemic has revealed many uncertainties in individuals' lives and when these uncertain situations are perceived as threatening, they can cause anxiety by causing negative reactions in the person. However, based on the results of this research, individuals can maintain their psychological resilience to the extent that they can use their spiritual resources during such trauma periods, which is stated to be the key to mental health during this Covid-19 outbreak period (Kluge, 2020a) and they can deal with the stress created by this uncertain situation more easily. So they can be said to lower their anxiety levels. From this point of view, psycho-social interventions focused on spirituality and psychological resilience during this period may help individuals to withstand uncertainty and improve their ability to cope with trauma, reducing their anxiety and anxiety levels.

Keywords: COVID-19, Anxiety, Spirituality, Resilience, Intolerance of Uncertainty, Path Analysis.

Öz: Bütün dünyayla birlikte ülkemizde de yayılmaya devam eden COVID-19 (Yeni Coranavirüs Hastalığı) salgını psikolojik baskıyı beraberinde getirmekte ve psikolojik dayanıklılığa meydan okumaktadır. Bu araştırmanın amacı, COVID-19 salgını sürecinde bireylerin kaygısı, psikolojik sağlamlık, maneviyat ve belirsizliğe tahammülsüzlük açısından incelemektir. Araştırmanın çalışma grubu uygun örnekleme yöntemi ile seçilen 565 (373 kadın, 192 erkek) yetişkin bireyden oluşmuştur. Araştırmanın yöntemi ilişkisel tarama modelindedir. Araştırmanın veri toplama araçları Demografik Bilgi Formu, Yaygın Anksiyete Bozukluğu Ölçeği, Belirsizliğe Tahammülsüzlük Ölçeği, Kısa Psikolojik Sağlamlık Ölçeği ve Manevi Yönelim Ölçeği'dir. Değişkenler arasındaki ilişkiler yol analizi ile test edilmiştir. Araştırmanın yapılabilmesi için gerekli olan etik kurul onayı alınmıştır. Önerilen modelin iyi uyum indekslerine sahip olduğu saptanmıştır $\left[\chi^{2 / \mathrm{df}_{(1)}=}\right.$ $.341(\mathrm{p}=.56), \mathrm{RMSEA}=.000, \mathrm{CFI}=1.00, \mathrm{GFI}=1.00, \mathrm{AGFI}=.99, \mathrm{NFI}=.99]$. Analiz sonuçlarında, maneviyat (sırasılya, $\beta=-.08, p<.01, \beta=-.10, p<.01, \beta=-.17, p<.01$ ) ve psikolojik sağlamlık (sırasıyla, $\beta=-.38, p<.01, \beta$ $=-.11, p<.01, \beta=-.49, p<.01)$ değişkenlerinin kaygıya doğrudan, dolaylı ve toplam olarak anlamlı ve negatif yönde etki yaptığı bulunmuştur. Belirsizliğe tahammülsüzlüğün kaygıyı doğrudan, anlamlı ve pozitif yönde ( $\beta$ $=.32, p<.01)$ etkilediği bulunmuştur. Ayrıca maneviyatın psikolojik sağlamlığı doğrudan, anlamlı ve pozitif yönde $(\beta=.20, p<.01)$; belirsizliğe tahammülsüzlüğü dolaylı, anlamlı ve negatif yönde $(\beta=-.07, p<.01)$;

Turkish Studies, 15(4) 
psikolojik sağlamlığın ise belirsizliğe tahammülsüzlüğü doğrudan, anlamlı ve negatif yönde $(\beta=-.36, p<.01)$ etkilediği bulunmuştur. Modelde kaygı $\% 35\left(\mathrm{R}^{2}=.35\right)$ oranında açıklanmıştır. Araştırmanın bulguları ilgili alan yazın çerçevesinde tartışılmıştır.

Anahtar Kelimeler: COVID-19, Kaygı, Maneviyat, Psikolojik Sağlamlık, Belirsizliğe Tahammülsüzlük, Yol Analizi.

\section{Giriş}

Çin'in Wuhan kentinde Aralık 2019'da başlayan ve dünyanın diğer bölgelerine de yayılan COVID-19 (Yeni Koronavirüs Hastalığı) salgını küresel bir sağlık tehdidi olarak karşımıza çıkmıştır (Cao vd., 2020; Wang vd., 2020). Ateş, öksürük ve nefes darlığ gibi belirtileri olan Covid-19, Türkiye'de ilk olarak 11 Mart’ta tespit edilmiştir (T.C. Sağlık Bakanlığı, 2020). Bu salgın psikolojik baskıya sebep olmakta ve psikolojik dayanıklılığa meydan okumaktadır (Cao vd., 2020; Wang vd., 2020). Ayrıca Dünya Sağlık Örgütü (DSÖ) bu durumun birçok kişide yaygın endişe, korku ve strese neden olduğunu bildirmektedir (www.euro.who.int).

Bu küresel salgın sürecinde Çin'de ve dünyanın farklı ülkelerinde genel halk, hastalar, sağlık personeli, çocuklar, öğrenciler ve yaşlılar üzerinde salgının psikolojik etkileri hakkında raporların yayınlanmaya başladığı görülmektedir (Asmundson \& Taylor, 2020; Bo vd., 2020; Cao vd., 2020; Chen vd., 2020; Chew vd., 2020; Huang \& Zhao, 2020; Jungmann \& Witthöft, 2020; Li vd., 2020; Lopes \& Jaspal, 2020; Meng vd., 2020; Moghanibashi-Mansourieh, 2020; Nemati vd., 2020; Ozamiz-Etxebarria vd., 2020; Özdin \& Bayrak Özdin, 2020; Pappa vd., 2020; Roy vd., 2020; Satici vd., 2020; Shanafelt vd., 2020; Shevlin vd., 2020; Soraci vd., 2020; Talidong \& Toquero, 2020; Tan vd., 2020; Yang vd., 2020; Zhang vd., 2020). Örneğin, Wang, Pan vd. (2020), salgının ilk aşamasında kayg1, depresyon ve stres düzeylerini daha iyi anlamak için Çin'deki kamuoyunu araştırmıştır. 194 şehirden 1.210 katılımcıdan oluşan bu çalışmada, katılımcıların \%54'ü salgının psikolojik etkisini orta veya şiddetli olarak derecelendirmiştir; \%17'si orta ve şiddetli depresif belirtiler bildirmiştir; $\% 29$ 'u orta ve şiddetli anksiyete belirtileri bildirmiştir ve \%8'i orta ve şiddetli stres seviyeleri bildirmiştir. Cao vd. (2020) ise Changzhi Tıp Fakültesi öğrencilerinin kaygı düzeylerini incelemiştir. Bulgular, katılımciların \%1'nin ciddi anksiyete, \%3'ünün orta derecede anksiyete ve $\% 21$ 'inin hafif anksiyete yaşadığını göstermiştir. Moghanibashi-Mansourieh (2020), İran toplumunun kayg1 düzeyini araştırmıştır. Analiz sonuçları, kadınlarda, COVID-19 ile ilgili haberleri daha fazla takip eden kişilerde, 21-40 yaş grubunda ve COVID-19 hastalığına yakalanan en az bir aile üyesi, akraba veya arkadaşı olan kişilerde kaygı düzeyinin daha yüksek olduğunu göstermiştir. Ozamiz-Etxebarria vd. (2020), İspanya'da yetişkin bireylerin anksiyete, stres ve depresyon düzeylerini incelemiştir. Bulgulara göre, salgın uyarısının başlangıcında semptom seviyeleri genellikle düşük olmasına rağmen, kronik hastalıkları olan genç bireyler nüfusun geri kalanından daha fazla semptom bildirmiştir. Çalışmada ayrıca evde kalma emri verildikten sonra daha yüksek semptom seviyeleri saptanmıştır. Shevlin vd. (2020), İngiltere'de, önceki nüfus çalışmalarına kıyasla daha yüksek düzeyde anksiyete, depresyon ve travma semptomları saptamıştır. Özdin ve Bayrak Özdin (2020), Türk toplumunda depresyon, anksiyete ve sağlık kaygısı düzeylerini değerlendirmeyi amaçlamıştır. Regresyon analizinde kadın cinsiyet, kentsel alanlarda yaşam ve önceki psikiyatrik hastalık öyküsü kayg1 için risk faktörü olarak; kentsel alanlarda yaşamak depresyon için risk faktörü olarak bulunmuştur; kadın cinsiyet, eşlik eden kronik hastalık ve daha önce psikiyatrik öykü sağlık kaygısı için risk faktörleri olarak bulunmuştur. Türk toplumunda yapılan başka bir çalışmada Satici vd. (2020), COVID-19 korkusunun depresyon, kaygı ve stresi artırdığını; yaşam doyumunu azalttığını saptamıştır. Bo vd. (2020), Çin'de, COVID-19 hastalarına yönelik bir çalışma yapmıştır. Analiz bulgularına göre, hastaların çoğunun taburcu olmadan önce anlamlı düzeyde travma sonrası stres semptomlarına sahip olduğu bulunmuştur. 
$\mathrm{Bu}$ araştırmada, COVID-19 salgınının ülkemizdeki bireyler üzerinde ortaya çıkan etkileri kayg1, belirsizliğe tahammülsüzlük, psikolojik sağlamlık ve maneviyat değişkenleri bağlamında incelemek amaçlanmıştır. Nitekim Salgınlara karşı insanların göstermiş oldukları psikolojik tepkiler, uyumsuz davranışları, duygusal sıkıntıları ve savunma tepkilerini içermektedir (Cullen vd., 2020). Kaygı, insanların zaman zaman yaşadığı, korkuya benzeyen bir duygudur. Birey bunu kötü bir haber alacakmış, bir felaket olacakmış gibi nedeni belli olmayan bir sıkıntı ve endişe duygusu olarak algılar ve yaşar (Gezgin vd., 2010). Bireylerde belirgin strese sebep olan, aşırı ve yaygın endişe hali ise yaygın kaygı bozukluğu olarak açıklanmaktadır (Karamustafalığlu \& Yumrukçal, 2011). Yapılan çalışmalarda kaygının psikolojik sağlamlıkla negatif (Açıkgöz, 2019; Hjemdal vd., 2011; Min vd., 2013; Perişan, 2018), belirsizliğe tahammülsüzlük ile pozitif (Belge, 2019; Dugas vd., 2001; Holaway vd., 2006; Sarı \& Dağ, 2009; Tantan Ulu, 2019) ve maneviyatla negatif yönde (Ai vd., 2005; Nelson vd., 2009; Reutter \& Bigatti, 2014) anlamlı bir ilişkisinin olduğu saptanmıştır. Glas ve Poort (2007) kaygı ve maneviyat ile ilgili yapılan çalışmaları derlemiş ve çeşitli durumlarda dindarlık / maneviyat ve kaygı arasında ilişki olduğunu, ancak nedensellik yönünün ve aracılık eden faktörlerin hala belirsiz olduğunu rapor etmişlerdir.

Belirsizliğe tahammülsüzlük (intolerance of uncertainty), bireyin gerçekleşme olasıllı̆̆ından bağımsız olarak gelecekteki olumsuz olayların potansiyel oluşumunu kabul edilemez olarak görme eğilimi olarak tanımlanmaktadır (Dugas vd., 2001). Alan yazında belirsizlik, geleceğin net olmama durumu (Sarıçam vd., 2014), yaşanan olaylara anlam vermedeki yetersizlikten kaynaklanan bilişsel bir durum (Crigger, 1996) olarak açıklanmaktadır. Belirsizlik birey üzerinde güçlü bir stres yaratmaktadır (Öz, 2001; Bailey vd., 2009). Belirsizliğe tahammülsüzlügü olan kişiler belirsiz durumlara karşı duygu, düşünce veya davranış şeklinde olumsuz tepkiler vermektedir (Buhr \& Dugas, 2002). Yapılan araştırmalarda belirsizliğe tahammülsüzlük patolojik endişe (Holaway vd., 2006), anksiyete bozukluğu belirtileri (Belge, 2019; Holaway vd., 2006; Sarı \& Dağ, 2009; Tantan Ulu, 2019), obsesif kompulsif bozukluk belirtileri (Holaway vd., 2006; Özkan, 2019), kendini engelleme ve mükemmeliyetçilik (Güvenç, 2019) ile pozitif; bilişsel esneklik (Güvenç, 2019) ve psikolojik dayanıklılık (Saatçı, 2020) ile negatif yönde ilişkili bulunmuştur.

DSÖ Avrupa direktörü Kluge, COVID-19 salgını sırasında psikolojik sağlamlığın fiziksel ve zihinsel sağlığın anahtarı olduğunu ifade etmiştir (Kluge, 2020a). Psikolojik sağlamlık (resilience), insanların önemli değişikliklerle ve/veya tehdit edici durumlarla üstesinden gelebilme kapasitesi; strese, sıkıntıya tepkilerdeki bireysel farklılıkların olumlu tarafinı ifade etmektedir (Rutter, 1987; Stewart vd., 1997). Psikolojik sağlamlığın bireyi risklerden koruyan, travmadan sonra bireyin büyümesini ve bu deneyimle kendini gerçekleştirmeye doğru bir adım atmasını sağlayan üçlü bir yapısı vardır (Richardson, 2002). Araştırmalar psikolojik sağlamlık seviyesi yüksek bireylerin ruhsal olarak daha sağliklı olduklarını (Cohan vd., 2006; Erarslan, 2014), zorluklar karşısında yılmadıklarını (Rahat, 2014; Steinhardt \& Dolbier, 2008; Terzi, 2006; Yalım, 2007) ve iyimser olduklarını (Benard, 2004) göstermektedir.

Alan yazında yapılan araştırmalarda maneviyat psikolojik sağlamlığın etkili bir faktörü olarak aktarılmışırı (Kim \& Ecquivel, 2011; Min vd., 2013; Pargament \& Cummings, 2010; Raghallaigh \& Giligan, 2010; Reutter \& Bigatti, 2014). Min vd. (2013), kayg1 bozukluğu olan ve düşük düzeyde psikolojik sağlamlık gösteren hastaların özelliklerini bulmayı amaçladıkları çalışmalarında, düşük maneviyatın güçlü şekilde düşük psikolojik sağlamlığı yordadığını bulmuştur. Yazarlar bu bulguya dayanarak kaygı bozukluğu olan hastaların psikolojik sağlamlığını artırmada maneviyatın önemini vurgulamıştır. Maneviyat bağlanma ilişkileri kurmaya yardımcı olarak, sosyal destek kaynaklarına erişim açarak, davranış ve ahlaki değerlere rehberlik ederek ve kişisel büyüme için firsatlar sunarak psikolojik sağlamlığı kolaylaştırabilmektedir (Crawford vd., 2006). İnsanlar travmatize olduklarında genellikle yaşamlarında yeni bir anlam ve amaç duygusu ararlar. Manevi veya dini inançlar ve uygulamalar neredeyse tüm kültürlerin önemli bileşenleri olarak görülmektedir. Maneviyat umut, hayatın anlamı, meditasyon ve dua, şefkat, sevgi, değerler, yüce bir gücün varlığına 
inanma ve aşkın olanla nihai soruları anlamak için kişisel bir arayışa dayanır (Dein, 2013; MoreiraAlmeida \& Koenig, 2006; Myers vd., 2000). Maneviyatın çeşitli tanımları vardır. Bu çalışmada maneviyat, "yaşamın maddi yönünün ötesine geçen aşkın bir güç veya varlık bilinci ve evrene derin bir bağll1ık ve bütünlük duygusunu içeren insan varoluşunun niteliği”" olarak tanımlanmıştır (Myers vd., 2000: 252). Manevi değerler ve uygulamalar insanların travmatik olayları nasıl yorumladıkları ve bunlarla nasıl başa çıkacakları üzerinde önemli bir etkiye sahip olabilir. Shaw, Joseph ve Linley (2005) travma sonrası büyüme ve din/maneviyat arasındaki ilişkiyi inceleyen 11 çalışmayı gözden geçirmiş ve üç ana bulgu ortaya çıkarmıştır. İlk olarak, bu çalışmalar din ve maneviyatın genellikle travma sonrasında insanlara faydalı olduğunu göstermektedir. İkincisi, travmatik deneyimler dinin veya maneviyatın derinleşmesine yol açabilir. Üçüncüsü, olumlu dini başa çıkma, dini açıklık, varoluşsal sorularla karşılaşmaya hazır olma, dini katılım ve içsel dindarlık tipik olarak travma sonrası büyüme ile ilişkilidir.

DSÖ'nün Avrupa Direktörü Kluge, böyle bir salgın ortamında, yaşamlarımızda ve topluluklarımızda bu kadar hızlı ortaya çıkan stresli durumu nasıl yönettiğimizin ve ona nasıl tepki verdiğimizin çok önemli olduğunu belirtmiştir (Kluge, 2020b). Travmatik olayların büyük etkisi, psikolojik sağlamlık faktörleri ve manevi inançların başa çıkma davranışı üzerindeki potansiyel etkileri göz önüne alındığında, travma zamanlarında psikolojik sağlamlığın geliştirilmesinde maneviyatın rolünün araştırılmasının insanın travmaya adaptasyon anlayışını ilerletebileceği ileri sürülmüştür (Peres vd., 2007).

COVID-19 salgını sırasında olumsuz psikolojik etkileri ve psikolojik semptomları azaltmak için kanıta dayalı stratejiler geliştirmek için araştırma verilerine ihtiyaç vardır. İlgili alan yazına dayanarak bu araştırmanın amacı, COVID-19 salgını ortamında maneviyatın, psikolojik sağlamlığın ve belirsizliğe tahammülsüzlüğün kaygıyı doğrudan ve/veya dolaylı ilişkilerle ne düzeyde açıkladığını incelemektir. Bu ilişkileri test etmek için oluşturulan modelin diyagramı aşağıda sunulmuştur (Şekil 1).

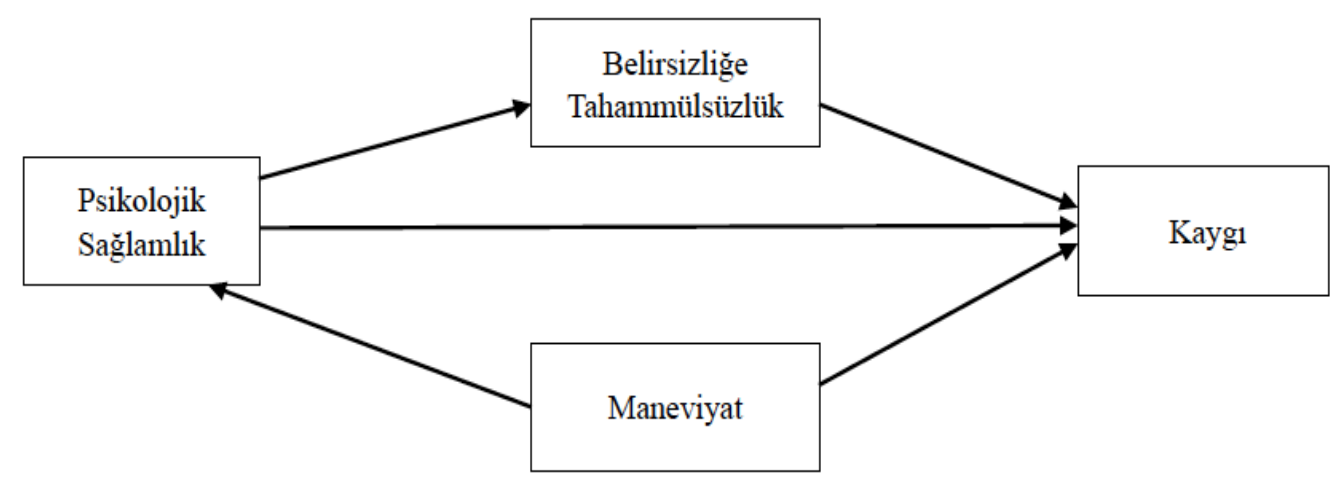

Şekil 1. Hipotez Modeli

\section{Yöntem}

\section{Araştırma Modeli}

$\mathrm{Bu}$ araştırma, değişkenler arasındaki ilişkiyi incelemeyi içeren ilişkisel araştırma modeline uygun olarak yapılmıştır (Büyüköztürk vd., 2010).

\section{Çalışma Grubu ve İşlem}

Araştırmanın çalışma grubu İstanbul'da yaşayan, uygun ve ulaşılabilir (Gravetter \& Forzano, 2012) yetişkin bireylerden oluşmuştur. Veri toplama araçlarının uygulanmasında, T.C. Sağlık Bakanlığı (www.saglik.gov.tr) halkın yüz yüze etkileşimini en aza indirmeyi ve halka evde 
kalmayı önerdiği için, online Google Form hizmetinin kullanılması planlanmıştır. Çalışmanın yapılabilmesi için İstanbul 29 Mayıs Üniversitesi Bilimsel Araştırma ve Yayın Etiği Kurulu'ndan onay alınmıştır (Karar No: 2020/01-01). Uygulama için İstanbul Valiliğii'nden gerekli izinler alınmıştır. Veriler Nisan-Mayıs 2020 tarihlerinde toplanmıştır. Ölçek formlarının uygulanmasında gönüllülük ilkesi göz önünde bulundurulmuş ve katılımcılardan gönüllü katılım onayı alınmıştır. Araştırmanın çalışma grubu, 18 ile 63 yaş aralığında (ortalama $=35.47$, ss $=9.99$ ), 373 kadın ve 192 erkek (sırasıyla \%66, \%34; $n=565)$ yetişkin bireyden oluşmuştur. Katılımcıların \%5.1'i $(n=29)$ ilkokul, \%1.8'i $(n=10)$ ortaokul, \%15.4'ü $(n=87), \% 58.8^{\prime} i(n=332)$ lisans ve \%18.9'u $(n=107)$ lisanüstü eğitime sahiptir. Katılımcıların \%40.5'i $(\mathrm{n}=229)$ memur, \%6's1 (n=34) işçi, \%1.2'si (n=7) esnaf, \%37.5'i (n=212) diğer (ev hanımı, çalışmıyor vb.) ve \%14.7'si (n=83) öğrencidir.

\section{Veri Toplama Araçları}

Demografik Bilgi Formu. Bireylerin yaşı, cinsiyeti, medeni durumu, eğitimi, mesleği gibi birtakım sorulardan oluşan araştırmacı tarafından hazırlanan formdur.

Yaygın Anksiyete Bozukluğu Ölçeği-7 (YAB-7). Spitzer vd. tarafından geliştirilmiş, yaygın anksiyete bozukluğunu değerlendiren 7 maddeli 4'lü likert tipi ( $0=$ hiç, $3=$ hemen her gün) bir ölçektir. Ölçekten edinilen toplam puanlar 5, 10, ve 15 sırasıyla hafif, orta ve ciddi anksiyete için kesme noktalarıdır (Konkan vd., 2013). Ölçek Konkan vd. (2013) tarafından Türkçe'ye uyarlanmıştır. YAB-7 Türkçe uyarlamasının toplam puanı için iç tutarlılı̆g $\alpha$.85 bulunmuştur. YAB7'nin Açımlayıcı Faktör Analizinde (AFA) özdeğeri >1 olan tek faktör oluştuğu ve bu faktörün toplam varyansın \%60.36 açıkladığı görülmüştür. Faktör yükleri .63 ile .84 arasında belirlenmiştir. Sonuçlar YAB-7 Türkçe formu faktör yapısının orijinaliyle benzer olduğunu ve yapısal geçerliliğinin iyi olduğunu göstermiştir. Ölçeğin tek faktörlü temel modeli için yapılan Doğrulayıcı Faktör Analizi (DFA) sonucunda uyum endeksleri $\left[\chi^{2}=147.20, \mathrm{sd}=14(\chi 2 / \mathrm{df} 1.034) \mathrm{RMSEA}=.018, \mathrm{CFI}=.998, \mathrm{GFI}=\right.$ $.965, \mathrm{NFI}=.944, \mathrm{RFI}=.916, \mathrm{IFI}=.998, \mathrm{TLI}=.997$ ve $\mathrm{AGFI}=.929]$ iyi düzeylerde bulunmuştur. $\mathrm{YAB}-$ 7-Türkçe formu ile durumluk ve süreklilik anksiyete arasında anlamlı ve ileri düzeyde korelasyon saptanmıştır (sırasıyla $\mathrm{r}=.57$ ve $\mathrm{r}=.67$ ).

Kısa Psikolojik Sağlamlık Ölçeği (KPSÖ). Ölçek Smith vd. (2008) tarafından bireylerin psikolojik sağlamlıklarını ölçmek amacıyla geliştirilmiştir ve Doğan (2015) tarafından Türkçe'ye uyarlanmıştır. Ölçek, 5'li likert tipinde, 6 maddeden oluşan bir özbildirim ölçeğidir. KPSÖ'nün faktör yapısını belirleyebilmek amacıyla AFA ve DFA yapılmıştır. AFA sonucunda, toplam varyansın \%54.66'sın1 açıklayan tek faktörlü bir yap1 elde edilmiştir. DFA sonucu, uyum indekslerinin uygun olduğu saptanmıştır $\left[\chi^{2} / \mathrm{sd}(12.86 / 7)=1.83, \mathrm{NFI}=0.99, \mathrm{NNFI}=0.99, \mathrm{CFI}=\right.$ $0.99, \mathrm{IFI}=0.99, \mathrm{RFI}=0.97, \mathrm{GFI}=0.99, \mathrm{AGFI}=0.96, \mathrm{RMSEA}=0.05, \mathrm{SRMR}=0.03]$. İç tutarlığ $\alpha=$ .81 olarak hesaplanmıştır. Ölçeğin puanlaması (1) 'Hiç katılmıyorum', (5) 'Tamamen katılıyorum' şeklindedir. Ölçekten alınan yüksek puan, psikolojik sağlamlığın yüksek olduğunu göstermektedir (Doğan, 2015).

Belirsizliğe Tahammülsüzlük Ölçeği (BTÖ-12). Ölçek Carleton vd. (2007) tarafindan geliştirilmiştir. Sarıçam vd. (2014), ölçeği Türkçe'ye uyarlamıştır. Ölçeğin yapı geçerliği için uygulanan DFA sonucunda orijinal formla tutarlı olarak 12 maddenin iki boyutta (ileriye yönelik kayg1 ve engelleyici kayg1) toplandığ1 görülmüştür $\left(\chi^{2}=147.20, \mathrm{sd}=48\right.$, RMSEA=.073, CFI=.95, $\mathrm{IFI}=.95, \mathrm{GFI}=.94, \mathrm{SRMR}=.046$ ). Ölçeğin faktör yükleri .55 ile .87 arasında sıralanmakta olup; iç tutarlık katsayı ölçeğin bütünü için $\alpha=.88$; ileriye yönelik kaygı alt boyutu için $\alpha=.84$, engelleyici kayg1 alt boyutu için $\alpha=.77$ olarak bulunmuştur. Ölçüt geçerliği çalışmasında belirsizliğe tahammülsüzlük ile başa çıkma esnekliği arasında negatif $(r=-.43)$; eğitim stresi ile .41 pozitif ilişki olduğu görülmüsstür. Test-tekrar test korelasyon katsayıs1 .74 olarak bulunmuş; ayrıca ölçeğin düzeltilmiş madde-toplam korelasyonlarının .42 ile .68 arasında sıralandığı görülmüştür. Ölçek, (1) 'bana hiç uygun değil' (5) 'bana tamamen uygun' şeklinde puanlanmaktadır. 
Manevi Yönelim Ölçeği (MYÖ). Bireylerin maneviyatını değerlendirmek için Kasapoğlu (2016) tarafından geliştirilmiştir. MYÖ, 7'li Likert tipi bir psikolojik ölçme aracıdır ve 16 maddeden oluşmaktadır. Ölçeğin yapı geçerliğini sınamak için AFA ve DFA yapılmıştır. AFA sonucuna göre ölçek, toplam varyansın \%47.50'sini açıklayan tek faktörden oluşmaktadır. DFA sonucunda, tek faktörlü yapının uyum indekslerinin uygun olduğu saptanmıştır $[(\chi 2=239.718, \mathrm{sd}=100, \mathrm{p}=.000), \chi 2 /$ $\mathrm{sd}=2.39, \mathrm{RMSEA}=0.06, \mathrm{RMR}=0.05, \mathrm{GFI}=0.93, \mathrm{AGFI}=0.90, \mathrm{CFI}=0.95, \mathrm{IFI}=0.95, \mathrm{NFI}=0.92]$. Ölçüt-bağımlı geçerlilik kapsamında Witmer ve Sweeney (1992) tarafından geliştirilen ve Doğan'ın (2004) Türkçe'ye uyarladığ 1 "İyilik Halini Değerlendirme Ölçeği”nin "maneviyat" alt ölçeği kullanılmıştır. MYÖ ile İyilik Halini Değerlendirme Ölçeğiı"nin "maneviyat" alt boyutu arasında anlamlı derecede pozitif yönlü ve orta düzeyde bir ilişki bulunmuştur $(r=.57 ; \mathrm{p}<.01)$. Ölçeğin iç tutarlı̆g $\alpha=.87$; test-tekrar test güvenirlik katsayısı, iki hafta arayla, $.84(\mathrm{p}=0.000)$ bulunmuştur (Kasapoğlu, 2016).

\section{Verilerin Analizi}

Veri giriş hataları veya eksik veriler $(\mathrm{n}=27)$ analiz dışı bırakılmıştır. Aykırı değerler Malahanobis uzaklığı ile hesaplanmış ve analizleri olumsuz etkileyecek veriler $(\mathrm{n}=97)$ analiz dışı bırakılmıştır. Sonuç olarak 565 veri ile analize devam edilmiştir. Tek ve çok değişkenli normallik çarpıklık ve basıklık katsayıları ile; YAB-7, KPSÖ, BTÖ-12 ve MYÖ’nin güvenilirlikleri Cronbach alfa katsayısı $(\alpha)$ ile incelenmiştir. Verilerin analizinde tanımlayı istatistikler ve Pearson Korelasyon Katsayısı uygulanmıştır (Tablo 1). Değişkenler arasındaki ilişkiler Yapısal Eşitlik Modeli uygulamalarından Yol (Path) Analizi ile araştırılmıştır. Analizler sonucunda elde edilen bulgular yorumlanırken $\mathrm{p}<.05$ anlamlılık düzeyi esas alınmış, analizler SPSS ve Amos programı ile yapılmıştır.

\section{Bulgular}

\section{Tanımlayıcı İstatistikler ve Korelasyon Analizi}

Çalışmanın değişkenleri arasındaki ilişkiler Pearson Korelasyon testi ile analiz edilmiştir. Değişkenler arasındaki korelasyon sonuçları alan yazınla tutarlı olarak beklenen yönde bulunmuş ve anlamlı sonuçlar $(p<0.01, p<0.05)$ vermiştir. Değişkenlere ilişkin tanımlayıcı istatistikler ve korelasyon değerleri Tablo 1'de gösterilmiştir.

Tablo 1: Tanımlayıcı, İç Tutarlık ve Pearson Korelasyon Katsayı İstatistikleri

\begin{tabular}{lrrrr}
\hline & Kaygı & $\begin{array}{c}\text { Psikolojik } \\
\text { Sağlamlık }\end{array}$ & $\begin{array}{r}\text { Belirsizliğe } \\
\text { Tahammülsüzlük }\end{array}$ & $\begin{array}{r}\text { Manevi } \\
\text { Yönelim }\end{array}$ \\
\hline Kaygı & & $-.51^{* *}$ & $.46^{* *}$ & $-.18^{* *}$ \\
Psikolojik Sağlamlı* & - & & $-.36^{* *}$ & $.20^{* *}$ \\
Belirsizliğe Tahammülsüzlük & & & & $-.09^{*}$ \\
\hline Ortalama & & & 36.33 & 107.52 \\
Standart Sapma & 6.74 & 20.75 & 10.6 & 5.96 \\
Çarpıklık & 5.48 & 4.79 & .11 & -1.61 \\
Basıklık & .73 & -.03 & -.56 & .90 \\
$\alpha$ & -.28 & -.08 & .78 & .90 \\
\hline
\end{tabular}

Tablo 1'deki değerlere bakıldığında, yaygın kaygı ile psikolojik sağlamlık $(r=-.51, p<0.01)$ ve manevi yönelim $(r=-.18, p<0.01)$ arasında negatif korelasyon; belirsizliğe tahammülsüzlük $(r=.46, p<0.01)$ arasında pozitif korelasyon bulunmuştur. Benzer şekilde, psikolojik sağlamlık ile belirsizliğe tahammülsüzlük $(r=-.36, p<0.01)$ negatif; manevi yönelim $(r=.20, p<0.01)$ pozitif ilişkili bulunmuştur. Belirsizliğe tahammülsüzlük ile manevi yönelim negatif ilişkili bulunmuştur $(r=-.09, p<0.05)$. Ölçeklerin iç tutarlık katsayılarının $(\alpha=.78$ ve .92$)$ yeterli düzeyde olduğu görülmüş̧ür (Büyüköztürk, 2010). 
Tablo 2'de YAB-7 puanlarının dağılımı gösterilmiştir. YAB-7 Ölçeğinde 5, 10 ve 15 puanları sırasıyla hafif, orta ve ciddi anksiyete için kesme noktaları olarak belirlenmiştir (Konkan vd., 2013).

Tablo 2: Katılımcıların YAB-7 Puanlarının Dağılımı

\begin{tabular}{rrrr}
\hline YAB-7 & $\mathrm{n}$ & $\%$ & Şiddeti \\
\hline $0-5$ puan & 274 & 48 & Hafif \\
6-10 puan & 163 & 29 & Orta \\
$11-15$ puan & 82 & 15 & Şiddetli \\
16-20 puan & 46 & 8 & Çok şiddetli \\
\hline
\end{tabular}

Tablo 2'de katılımcılardan \%48'inin hafif, \%29'unun orta, \%15'inin şiddetli, \%8'inin ise çok şiddetli kaygı yaşadığı görülmektedir.

\section{Yol Analizinde Elde Edilen Bulgular}

Kaygının maneviyat, psikolojik sağlamlık ve belirsizliğe tahammülsüzlük açısından doğrudan ve dolaylı ilişkilerle açıklanma gücünün belirlenmesi amacıyla yol analizi yapılmış ve test edilen model Şekil 2'de gösterilmiştir.

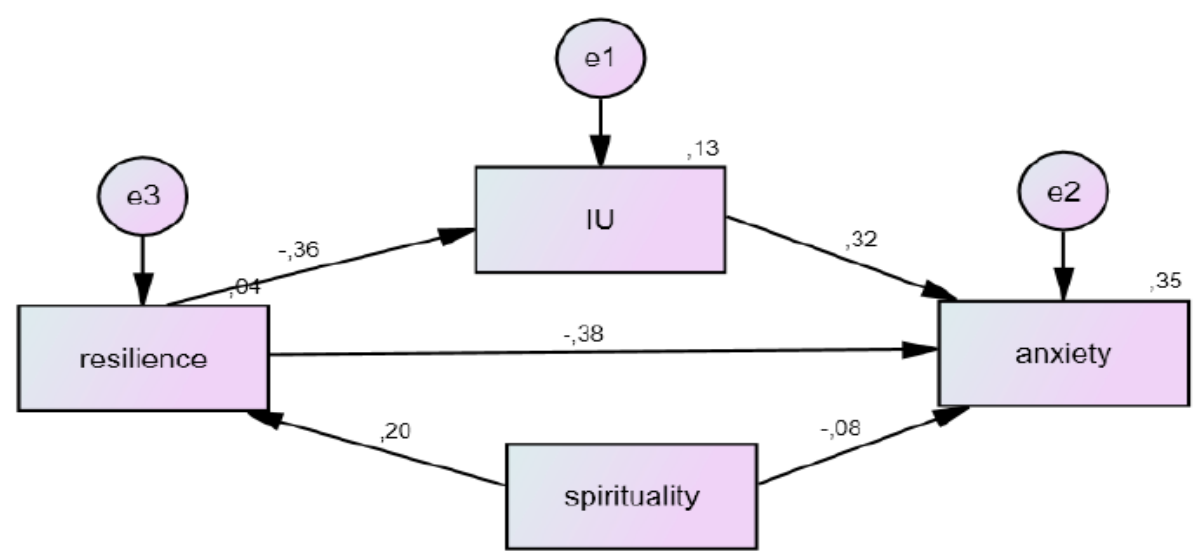

Şekil 2. Test Edilen Model

Oluşturulan modelin uyum indeksleri, $\chi 2 / \mathrm{df}_{(1)}=.341(p=.559)$, RMSEA $=.000, \mathrm{CFI}=1.00$, $\mathrm{GFI}=1.00, \mathrm{AGFI}=.99, \mathrm{NFI}=.99$ değerle iyi düzeyde uyum göstermiştir (Hu \& Bentler, 1999; Kline, 2015; Şimşek, 2007) Elde edilen sonuçlar yol analizinde istatistiksel olarak bütün yolların anlamlı olduğunu göstermiştir. Kurulan model sonucunda elde edilen standartlaştırılmamış regresyon katsayıları (b), standartlaştırılmış regresyon katsayıları ( $\beta$ ), standart hatalar (SH), kritik oranlar (KO) ve $\mathrm{p}$ değerleri Tablo 3 'te verilmiştir.

Tablo 3: Yol Analizinde Parametre Tahminleri

\begin{tabular}{lllrrrrr}
\hline \multicolumn{1}{c}{ Yol } & & & $\mathrm{b}$ & $\beta$ & $\mathrm{SH}$ & C.R. & P \\
\hline Psikolojik Sağlamlık & $<---$ & Maneviyat & .159 & .197 & .033 & 4.784 & $* * *$ \\
Belirsizliğe & $<---$ & Psikolojik Sağlamlık & -.790 & -.357 & .087 & -9.068 & $* * *$ \\
Tahammülsüzlük & & & & & & & \\
Kayg1 & $<---$ & Maneviyat & -.071 & -.077 & .032 & -2.216 & $* *$ \\
Kayg1 & $<---$ & Belirsizliğe & .163 & .316 & .019 & 8.674 & $* * *$ \\
& & Tahammülsüzlük & & & & & \\
Kayg1 & $<---$ & Psikolojik Sağlamlık & -.432 & -.378 & .042 & -10.196 & $* * *$ \\
$* * * p<.001, * * p<.05$ & & & & & & &
\end{tabular}

Bağımsız değişkenlerin bağımlı değişkenler üzerindeki doğrudan, dolaylı ve toplam etkileri Tablo 4'te verilmiştir. 
Tablo 4: Değişkenler Arasındaki Doğrudan, Dolaylı ve Toplam Etkiler (Standardize Edilmiş)

\begin{tabular}{|c|c|c|c|c|c|c|c|c|c|}
\hline \multirow{3}{*}{ Yordanan Değişkenler } & \multicolumn{9}{|c|}{ Yordayıcı Değişkenler } \\
\hline & \multicolumn{3}{|c|}{ Maneviyat } & \multicolumn{3}{|c|}{$\begin{array}{l}\text { Psikolojik } \\
\text { Sağlamlık }\end{array}$} & \multicolumn{3}{|c|}{$\begin{array}{r}\text { Belirsizliğe } \\
\text { Tahammülsüzlük }\end{array}$} \\
\hline & 1 & 2 & 3 & 1 & 2 & 3 & 1 & 2 & 3 \\
\hline Psikolojik Sağlamlık & .20 & .00 & .20 & .00 & .00 & .00 & .00 & .00 & .00 \\
\hline Belirsizliğe Tahammülsüzlük & .00 & -.07 & -.07 & -.36 & .00 & -.36 & .00 & .00 & .00 \\
\hline Kayg1 & -.08 & -.10 & -.17 & -.38 & -.11 & -.49 & .32 & .00 & .32 \\
\hline
\end{tabular}

Not: 1=Doğrudan, $2=$ Dolayl1, $3=$ Toplam

Modelde maneviyatın, psikolojik sağlamlığın yaygın kaygı üzerindeki dolaylı etkisinin anlamlılığını test etmek için bootstrapping yöntemi (1000 bootstrapping örneklemi) kullanılmış ve güven aralığ $1 \% 95$ olarak alınmıştır. Elde edilen değerler Tablo 5 'te gösterilmiştir.

Tablo 5: Değişkenler Arasındaki Dolaylı Etkilerin Anlamlılık (p) Değerleri

\begin{tabular}{lccc}
\hline & Maneviyat & $\begin{array}{c}\text { Psikolojik } \\
\text { Sağlamlık }\end{array}$ & $\begin{array}{r}\text { Belirsizliğe } \\
\text { Tahammülsüzlük }\end{array}$ \\
\hline Psikolojik Sağlamlık & $\ldots$ & $\ldots$ & $\ldots$ \\
Belirsizliğe Tahammülsüzlük & .001 & $\ldots$ & $\ldots$ \\
Kayg1 & .001 & .001 & $\ldots$ \\
\hline
\end{tabular}

Yapılan yol analizinde Tablo 3, 4 ve 5 birlikte değerlendirildiğinde, maneviyat (sırasıyla, $\beta$ $=-.08, \mathrm{p}<.01, \beta=-.10, \mathrm{p}<.01, \beta=-.17, \mathrm{p}<.01$ ) ve psikolojik sağlamlık (srasılyla, $\beta=-.38, \mathrm{p}<.01, \beta=-$ $.11, \mathrm{p}<.01, \beta=-.49, \mathrm{p}<.01$ ) değişkenlerinin kaygıya doğrudan, dolaylı ve toplam olarak anlamlı ve negatif yönde etki yaptığı bulunmuştur. Sonuçlar ayrıca belirsizliğe tahammülsüzlüğün kaygıyı doğrudan, anlamlı ve pozitif yönde $(\beta=.32, \mathrm{p}<.01)$ etkilediğini göstermiştir. Diğer bulgulara göre, maneviyat psikolojik sağlamlığı doğrudan, anlamlı ve pozitif yönde $(\beta=.20, p<.01)$; belirsizliğe tahammülsüzlüğü dolaylı, anlamlı ve negatif yönde $(\beta=-.07, p<.01)$; psikolojik sağlamlık belirsizliğe tahammülsüzlügü doğrudan, anlamlı ve negatif yönde $(\beta=-.36, p<.01)$ etkilemiştir. Yol analizinin bulguları, maneviyatın kaygıya hem doğrudan hem de psikolojik sağlamlık üzerinden dolaylı ve anlamlı etkisinin olduğunu; psikolojik sağlamlığın kaygıya hem doğrudan hem de belirsizliğe tahammülsüzlük üzerinden dolaylı olarak anlamlı etkisinin olduğunu göstermektedir. Modelde kayg1 $\% 35\left(\mathrm{R}^{2}=.35\right)$ oranında açıklanmaktadır.

\section{Tartışma}

Bu çalışmada COVID-19 pandemisinde İstanbul'da yaşayan bireylerin kaygı düzeylerinde maneviyat, psikolojik sağlamlık ve belirsizliğe tahammülsüzlüğ̈̈n etkisi bir model öne sürülerek yol analizi ile incelenmiştir. Elde edilen sonuç, maneviyatın kaygıya hem doğrudan hem de psikolojik sağlamlık üzerinden dolaylı ve anlamlı etkisinin olduğunu; psikolojik sağlamlığın kaygıya hem doğrudan hem de belirsizliğe tahammülsüzlük üzerinden dolaylı olarak anlamlı etkisinin olduğunu göstermektedir. Bu bulgudan hareketle, COVID-19 salgını döneminde bireylerin maneviyatları güçlü olduğunda psikolojik sağlamlık düzeyleri yüksek olmakta ve belirsizliğe tahammül düzeyleri artmakta ve böylece kaygı̈ düzeyleri azalmaktadır sonucuna varılabilir.

$\mathrm{Bu}$ çalışmada öncelikle katılımcıların kaygı düzeyleri incelenmiştir. Sonuç olarak katılımcıların yaklaşık yarısı (\%48) hafif, \%29'u orta ve \%23'ü şiddetli anksiyete bildirmiştir. Benzer bulgular Çin'de ve diğer ülkelerde yapılan çalışmalarda da tespit edilmiştir (Cao vd., 2020; Özdin \& Bayrak Özdin, 2020; Moghanibashi-Mansourieh, 2020; Shevlin vd., 2020; Wang vd., 2020). Wang vd. (2020)'nin Çin'deki kamuoyu araştırmasında, katılımcıların \%54'ü salgının psikolojik etkisini orta veya şiddetli olarak derecelendirmiştir; \%29'u orta ve şiddetli kaygı belirtileri bildirmiştir. Cao vd. (2020) Changzhi Tıp Fakültesi öğrencilerinin \%1'nin ciddi kaygı, \%3'ünün orta derecede kaygı ve \%21'inin hafif kaygı yaşadığını saptamıştır. Özdin ve Bayrak Özdin (2020), 
göreceli olarak yüksek depresyon ve kaygı düzeyleri (sırasıyla \% 24 ve $\% 45$ ) tespit etmiştir. Salgın sırasında virüsün yayılımını azaltmak için evde kalma, fiziksel mesafeyi koruma zorunluğu gibi çeşitli önlemler alınmaktadır. Diğer taraftan, hastalığa yakalanan hasta sayısı ve ölüm oranları artmaya devam etmektedir. Bütün bu faktörler toplumun ruh sağlı̆̆ olabilir. Dolayısıyla çalışmada elde edilen bu anksiyete bulgularının pandemik psikolojik etkiler açısından beklenen bulgular olduğu söylenebilir.

Araştırmada doğrulanan modele göre, maneviyat kaygıyı hem doğrudan hem de psikolojik sağlamlık üzerinden negatif yönde etkilemiştir. Bireylerin maneviyat düzeyi yüksek olduğunda psikolojik sağlamlığı güçlü olmakta, diğer bir deyişle, stres ve sıkıntıya olumlu tepki vermekte (Rutter, 1987) ve kaygı düzeyi azalmaktadır. Alan yazında yapılan çalışmalara bakıldığında maneviyatın kaygıyla negatif yönde ve anlamlı bir ilişkisinin olduğu görülmektedir (Glas \& Poort, 2007; Nelson vd., 2009; Reutter \& Bigatti, 2014). Diğer taraftan çalışmalarda maneviyatın psikolojik sağlamlığın etkili ve temel kaynaklarından biri olduğu belirtilmektedir (Kim \& Esquivel, 2011; Pargament ve Cummings, 2010; Raghallaigh \& Giligan, 2010; Reutter \& Bigatti, 2014). Maneviyat, özelikle içinde bulunduğumuz COVID-19 pandemisinin yarattığ 1 travma dönemlerinde kişilerin yaşamlarında yeni bir anlam ve amaç duygusu geliştirmelerine, umutlarını sürdürmelerine, kutsal ile bağlantı kurarak sorunlarını anlamlandırmaya çalışmalarına kaynaklık edebilir ve bireyler bu sayede psikolojik sağl1klarını koruyabilir, stres ve sıkıntılı durumlarla pozitif bir şekilde baş edebilirler. Shaw vd. (2005) alan yazında yapılan bazı çalışmaları birlikte değerlendirmiş ve manevi değerlerin genellikle travma sonrasında arttığı ve derinleştiği ve kişilere faydalı olduğu, varoluşsal sorularla karşılaşmaya hazır duruma getirdiği ve travma sonrası büyümeye katkı sağladığı sonucuna varmışladır.

Doğrulanan modelin diğer bulgusuna göre, psikolojik sağlamlığın kaygı üzerinde hem doğrudan hem de belirsizliğe tahammülsüzlük aracılığıyla etkisi vardır. Modele dayanarak kişinin psikolojik sağlamlığı yüksekse, diğer bir deyişle, stres ve sıkıntıya verdiği tepki olumluysa (Rutter, 1987) daha düşük kaygı düzeyinin olacağı öngörülebilir. Bu bulgu alan yazınla tutarlıdır (Açıkgöz, 2019; Hjemdal vd., 2011; Min vd., 2013; Perişan, 2018). Ayrica test edilen modelde psikolojik sağlamlığın belirsizliğe tahammülsüzlüğü negatif yönde etkilediği bulunmuştur. Bu sonuca göre, bireylerin psikolojik sağlamlığ 1 güçlü olduğunda beklenmeyen olaylara karşı duygu, düşünce veya davranış olarak başa çıkmada daha başarılı olacakları öngörülebilir. Alan yazın bu sonucu desteklemektedir (Saatç1, 2020; Tompkins \& Adger, 2004). Doğrulanan modelde, belirsizliğe tahammülsüzlüğün kaygıya pozitif yönde etki yapmıştığı bulunmuştur. Bireylerin belirsizliğe tahammülsüzlük düzeyleri düştükçe kaygı düzeyleri de düşmektedir. Buna göre, bireyin belirsizliğe tahammül düzeyinin artması, diğer bir deyişle, belirsizliğin yarattı̆̆ strese karşı (Öz, 2001; Bailey vd., 2009) olumlu tepkiler vermesi kaygı düzeyini düşürmektedir. Alan yazında yapılan çalışmalar bu bulguyu destekler niteliktedir (Belge, 2019; Greco \& Roger, 2003; Holaway vd., 2006; Sar1 \& Dağ, 2009; Tantan Ulu, 2019). Diğer taraftan, belirsizliği tolere edemeyen bireylerin belirsiz sonuçlarla meşgul olmaları, kaygının devam etmesine ve hatta kaygı düzeyinin artmasına neden olmaktadır (Dugas vd., 2001).

COVID-19 pandemisi bireylerin yaşamında pek çok belirsizlik ortaya çıkarmakta ve bu belirsiz durumlar tehdit edici olarak algılandığında kişide olumsuz tepkilere yol açarak kaygıya neden olabilmektedir. Bununla birlikte, bu araştırmanın sonuçlarından yola çıkarak, bireylerin böyle travma dönemlerinde manevi kaynaklarını kullanabildikleri ölçüde psikolojik sağlamlıklarını koruyabilecekleri, - ki psikolojik sağlamlığın bu COVID-19 salgını döneminde ruh sağlığının anahtarı (Kluge, 2020a) olduğu belirtilmektedir — bu belirsiz durumun yarattığı stresle daha kolay baş edebilecekleri ve böylece kaygı düzeylerini düşürebilecekleri söylenebilir. Buradan hareketle bu dönemde ruh sağlığı uzmanları tarafından yapılacak maneviyat ve psikolojik sağlamlık odaklı psikososyal müdahaleler halkın belirsizliğe dayanmalarına ve travmayla başa çıkma yetilerini geliştirmelerine yardımcı olarak kaygı ve endişe seviyelerini azaltmaya olanak sağlayabilir. 
$\mathrm{Bu}$ araştırmanın bazı sınırlılıkları bulunmaktadır. Öncelikle, veriler klinik belirti göstermeyen örneklemden toplanmıştır. Bu yüzden klinik vakalara genellenemez. İkinci olarak, bulgular öz-bildirim ölçeklerinden elde edilen verilere dayanmaktadır. Bu durum kaynak yanlılığı riski taşımaktadır. Sınılılıklarına rağmen bu çalışmanın bulgularının, ruh sağlığı uzmanlarına COVID-19 salgınının sebep olduğu ruh sağlığı sorunları ile başa etmede yardımcı olacağı düşünülmektedir.

\section{Kaynakça}

Açıkgöz, S. C. (2019). Depresyon, panik bozukluk ve yaygın anksiyete bozukluğunun psikolojik sağlamlık/dayanıklılık ile iliş̧isi [Yayınlanmamış yüksek lisans tezi]. İstanbul Okan Üniversitesi Sosyal Bilimler Enstitüsü.

Agaibi, C. E., \& Wilson, J. P. (2005). Trauma, PTSD, and resilience: A review of the literature. Trauma, $\quad$ Violence, $\quad \& \quad$ Abuse, 6(3), 195-216. https://doi.org/10.1177\%2F1524838005277438

Ai, A. L., Cascio, T., Santangelo, L. K., \& Evans-Campbell, T. (2005). Hope, meaning, and growth following the September 11, 2001, terrorist attacks. Journal of Interpersonal Violence, 20(5), 523-548. https://doi.org/10.1177\%2F0886260504272896

Asmundson, G. J., \& Taylor, S. (2020). How health anxiety influences responses to viral outbreaks like COVID-19: What all decision-makers, health authorities, and health care professionals need to know. Journal of Anxiety Disorders, 71, 102211. https://dx.doi.org/10.1016\%2Fj.janxdis.2020.102211

Bailey, D.E., Jr., Landerman, L., Barroso, J., Bixby, P., Mishel, M.H., Muir, A.J., . . Clipp, E. (2009). Uncertainty, symptoms, and quality of life in persons with chronic hepatitis C. Psychosomatics, 50, 138-146. https://doi.org/10.1176/appi.psy.50.2.138

Belge, J. (2019). Bir grup yetişkinde depresif semptomlar, anksiyete semptomları ve belirsizliğe tahammülsüzlük arasındaki ilişsinin belirlenmesi [Yayınlanmamış yüksek lisans tezi]. İstanbul Gelişim Üniversitesi Sosyal Bilimler Enstitüsü.

Benard, B. (2004). Resiliency: What we have learned. WestEd Publishers.

Bo, H., Li, W., Yang, Y., Wang, Y., Zhang, Q., Cheung, T., Wu, X., \& Xiang, Y. (2020). Posttraumatic stress symptoms and attitude toward crisis mental health services among clinically stable patients with COVID-19 in China. Psychological Medicine as part of the Cambridge Coronavirus Collection. https://doi.org/10.1017/S0033291720000999

Buhr, K., \& Dugas, M. J. (2002). The Intolerance of Uncertainty Scale: Psychometric properties of the English version. Behaviour research and therapy, 40(8), 931-945. https://doi.org/10.1016/S0005-7967(01)00092-4

Büyüköztürk, Ş., Çakmak, E.K., Akgün, Ö.E., Karadeniz, Ş., \& Demirel F. (2010). Bilimsel araştırma yöntemleri (5. baskı). Pegem Akademi.

Cao, W., Fang, Z., Hou, G., Han, M., Xu, X., Dong, J., \& Zheng, J. (2020). The psychological impact of the COVID-19 epidemic on college students in China. Psychiatry Research, 112934. https://doi.org/10.1016/j.psychres.2020.112934

Chen, P., Mao, L., Nassis, G.P., Harmer, P., Ainsworth, B.E., \& Li, F. (2020). Wuhan coronavirus (2019-nCoV): The need to maintain regular physical activity while taking precautions. Journal of Sport and Health Science, 9(2), 103-104. https://dx.doi.org/10.1016\%2Fj.jshs.2020.02.001 
Chew, N. W., Lee, G. K., Tan, B. Y., Jing, M., Goh, Y., Ngiam, N. J., ... \& Sharma, A. K. (2020). A multinational, multicentre study on the psychological outcomes and associated physical symptoms amongst healthcare workers during COVID-19 outbreak. Brain, behavior, and immunity. https://doi.org/10.1016/j.bbi.2020.04.049

Crawford, E., Wright, M., \& Masten, A. S. (2006). Resilience and spirituality in youth. In E.C. Roehlkepartain, P. E., King, L. Wagener., \& P. L. Benson (Eds.), The handbook of spiritual development in childhood and adolescence (pp. $355-370$ ). Sage.

Cohan, L., Sills, C., \& Stein, B. (2006). Relationship of resilience to personality, coping and psychiatric symptoms in young adults. Behaviour Research and Therapy, 44, 585-599. https://doi.org/10.1016/j.brat.2005.05.001

Crigger, N. J. (1996). Testing an uncertainty model for women with multiple sclerosis. Advanced in Nursing Science, 18(3), 37-47. doi:10.1097/00012272-199603000-00005

Cullen, W., Gulati, G., \& Kelly, B.D. (2020). Mental health in the Covid-19 pandemic. Published by Oxford University Press on behalf of the Association of Physicians. https://mc.manuscriptcentral.com/qjm

Dein, S. (2013). Religion, spirituality, depression, and anxiety: Theory, research, and practice. In K. I. Pargament (Ed.). APA handbook of psychology, religion and spirituality: Vol. 2. An applied psychology of religion and spirituality (pp. 241-255). American Psychological Association. https://psycnet.apa.org/doi/10.1037/14046-012

Doğan, T. (2015). Kısa psikolojik sağlamlık ölçeği’nin Türkçe uyarlaması: Geçerlik ve güvenirlik çalışması. The Journal of Happiness \& Well-Being, 3(1), 93-102.

Dugas, M. J., Gosselin, P., \& Ladouceur, R. (2001). Intolerance of uncertainty and worry: investigating specificity in a nonclinical sample. Cognitive Therapy and Research, 25, 551558.doi:10.1023/a:1005553414688

Erarslan, Ö. (2014). Üniversite ögrrencilerinde psikolojik sağlamlık ile depresif belirtiler ve yaşam memnuniyeti arasındaki ilişkide benlik saygısı, pozitif dünya görüşü ve umudun aracı rolünün incelenmesi [Yayımlanmamış yüksek lisans tezi]. Hacettepe Üniversitesi.

Gezgin, H., Çam, O., \& Karademir, M. (2010). Yaygın anksiyete bozukluğu tanılı bireylere verilen psikoeğitimin tedavideki etkinliğinin incelenmesi. Klinik Psikiyatri, 13, 65-76.

Glas, G., \& Poort, Z. (2007). Anxiety, anxiety disorders, religion and spirituality. Southern medical journal, 100(6), 621-625.

Gravetter, J. F., \& Forzano, L. B. (2012). Research methods for the behavioral sciences (4th ed.). Wadsworth, Cengage Learning.

Güvenç, F. (2019). Üniversite ögrencilerinde bilişsel esneklik ve belirsizliğe tahammülsüzlük ile kişilik özellikleri arasındaki ilişki [Yayınlanmamış yüksek lisans tezi]. Necmettin Erbakan Üniversitesi Eğitim Bilimleri Enstitüsü.

Hjemdal, O., Vogel, P. A., Solem, S., Hagen, K., \& Stiles, T. C. (2011). The relationship between resilience and levels of anxiety, depression, and obsessive-compulsive symptoms in adolescents. Clinical Psychology and Psychotherapy, 18(4), 314-321. https://doi.org/10.1002/cpp.719

Holaway, R. M., Heimberg, R. G., \& Coles, M. E. (2006). A comparison of intolerance of uncertainty in analogue obsessive-compulsive disorder and generalized anxiety disorder. Journal of Anxiety Disorders, 20(2), 158-174. https://doi.org/10.1016/j.janxdis.2005.01.002 
Hu, L. T., \& Bentler, P. M. (1999). Cutoff criteria for fit indexes in covariance structure analysis: Conventional criteria versus new alternatives. Structural Equation Modeling: A Multidisciplinary Journal, 6(1), 1-55. doi:org/10.1080/10705519909540118

Huang, Y., \& Zhao, N. (2020). Generalized anxiety disorder, depressive symptoms and sleep quality during COVID-19 outbreak in China: a web-based cross-sectional survey. Psychiatry research, 112954. https://doi.org/10.1016/j.psychres.2020.112954

Jungmann, S. M., \& Witthöft, M. (2020). Health anxiety, cyberchondria, and coping in the current COVID-19 pandemic: Which factors are related to coronavirus anxiety? Journal of Anxiety Disorders, 102239. https://doi.org/10.1016/j.janxdis.2020.102239

Karamustafalığlu, O., \& Yumrukçal, H. (2011). Depresyon ve anksiyete bozuklukları. Şişli Etfal Hastanesi Tıp Bülteni, 45(2), 65-74.

Kasapoğlu, F. (2016). Manevi Yönelim Ölçeği'nin geliştirilmesi: Geçerlik ve güvenirlik çalışması. İnönü Üniversitesi Eğitim Fakültesi Dergisi, 16(3), 51-68. doi:org/10.17679/iuefd.16360640

Kim, S., \& Esquivel, G. B. (2011). Adolescent spirituality and resilience: Theory, research, and educational practices. Psychology in the Schools, 48(7), 755-765. https://doi.org/10.1002/pits.20582

Kline, R. B. (2015). Principles and practice of structural equation modeling. Guilford Publications.

Kluge, H. H. P. (2020a). Statement - Physical and mental health key to resilience during COVID-19 pandemic. 26 March 2020, Copenhagen, Denmark. http://www.euro.who.int/en/mediacentre/sections/statements/2020/statement-physical-and-mental-health-key-to-resilienceduring-covid-19-pandemic

Kluge, H. H. P. (2020b). Mental health and psychological resilience during the COVID-19 pandemic. http://www.euro.who.int/en/health-topics/health-emergencies/coronavirus-covid19/news/news/2020/3/mental-health-and-psychological-resilience-during-the-covid-19pandemic

Konkan, R., Şenormanc1, Ö., Güçlü, O., Aydin, E., \& Sungur, M. Z. (2013). Yaygın Anksiyete Bozukluğu-7 (YAB-7) Testi Türkçe Uyarlamas1, Geçerlik ve Güvenirliği. Archives of Neuropsychiatry/Noropsikiatri Arsivi, 50(1), 53-58.

Li, S.W., Wang, Y., Yang, Y.Y., Lei, X.M., \& Yang, Y.F. (2020). Analysis of influencing factors of anxiety and emotional disorders in children and adolescents during home isolation during the epidemic of novel coronavirus pneumonia. Chinese Journal of Child Health. 1-9.

Lopes, B. C. d. S., \& Jaspal, R. (2020). Understanding the mental health burden of COVID-19 in the United Kingdom. Psychological Trauma: Theory, Research, Practice, and Policy, 12(5), 465-467. http://dx.doi.org/10.1037/tra0000632

Meng, H., Xu, Y., Dai, J., Zhang, Y., Liu, B., \& Yang, H. (2020). The psychological effect of COVID-19 on the elderly in China. Psychiatry Research, 112983. https://dx.doi.org/10.1016\%2Fj.psychres.2020.112983

Min, J. A., Jung, Y. E., Kim, D. J., Yim, H. W., Kim, J. J., Kim, T. S., ... \& Chae, J. H. (2013). Characteristics associated with low resilience in patients with depression and/or anxiety disorders. Quality of Life Research, 22(2), 231-241.

Moghanibashi-Mansourieh, A. (2020). Assessing the anxiety level of Iranian general population during COVID-19 outbreak. Asian journal of psychiatry, 102076. https://doi.org/10.1016/j.ajp.2020.102076 
Moreira-Almeida, A., \& Koenig, H. G. (2006). Retaining the meaning of the words religiousness and spirituality. Social Science \& Medicine, 63(4), 840-845. https://doi.org/10.1016/j.socscimed.2006.03.001

Myers, J. E., Sweeney, T. J., \& Witmer, J. M. (2000). The wheel of wellness counseling for wellness: A holistic model for treatment planning. Journal of Counseling and Development, 78(3), 251-266. doi:org/10.1002/j.1556-6676.2000.tb01906.x

Nelson, C., Jacobson, C. M., Weinberger, M. I., Bhaskaran, V., Rosenfeld, B., Breitbart, W., \& Roth, A. J. (2009). The role of spirituality in the relationship between religiosity and depression in prostate cancer patients. Annals of Behavioral Medicine, 38(2), 105-114. https://doi.org/10.1007/s12160-009-9139-y

Nemati, M., Ebrahimi, B., \& Nemati, F. (2020). Assessment of Iranian nurses' knowledge and anxiety toward COVID-19 during the current outbreak in Iran. Archives of Clinical Infectious Diseases, 15(COVID-19). http://dx.doi.org/10.5812/archcid.102848

Ozamiz-Etxebarria, N., Dosil-Santamaria, M., Picaza-Gorrochategui, M., \& Idoiaga-Mondragon, N. (2020). Stress, anxiety, and depression levels in the initial stage of the COVID-19 outbreak in a population sample in the northern Spain. Cadernos de Saúde Pública, 36, e00054020. https://doi.org/10.1590/0102-311X00054020

Öz, F. (2001) Hastalık yaşantısında belirsizlik. Türk Psikiyatri Dergisi, 12(1), 61-68.

Özkan, Ö. S. (2019). Obsesif kompulsif bozukluk tanısı almış hastalarda belirsizliğe tahammülsüzlük ve agresyon arasındaki ilişsinin incelenmesi [Yayınlanmamış yüksek lisans tezi]. Üsküdar Üniversitesi Sosyal Bilimler Enstitüsü.

Özdin, S., \& Bayrak Özdin, Ş. (2020). Levels and predictors of anxiety, depression and health anxiety during COVID-19 pandemic in Turkish society: The importance of gender. International Journal of Social Psychiatry, 0020764020927051. https://doi.org/10.1177\%2F0020764020927051

Pappa, S., Ntella, V., Giannakas, T., Giannakoulis, V. G., Papoutsi, E., \& Katsaounou, P. (2020). Prevalence of depression, anxiety, and insomnia among healthcare workers during the COVID-19 pandemic: A systematic review and meta-analysis. Brain, behavior, and immunity. https://doi.org/10.1016/j.bbi.2020.05.026

Peres, J. F., Moreira-Almeida, A., Nasello, A. G., \& Koenig, H. G. (2007). Spirituality and resilience in trauma victims. Journal of religion and health, 46(3), 343-350.

Perişan, N. (2018) Kaygı, psikolojik dayanıklılık ve başa çıkma yolları arasındaki ilişski: Üst bilişin aracı rolü [Yayınlanmamış yüksek lisans tezi]. Maltepe Üniversitesi Sosyal Bilimler Enstitüsü.

Rahat, E. (2014). Benlik kurgusu, sosyal destek, başa çıkma stilleri ve yılmazlı̆̆ın üniversite yaşamına uyumu yordama güçlerinin incelenmesi [Yayımlanmamış yüksek lisans tezi]. Gaziosmanpaşa Üniversitesi.

Reutter, K. K., \& Bigatti, S. M. (2014). Religiosity and spirituality as resiliency resources: Moderation, mediation, or moderated mediation? Journal for the scientific study of religion, 53(1), 56-72. https://doi.org/10.1111/jssr.12081

Richardson, G. E. (2002). The metatheory of resilience and resiliency. Journal of Clinical Psychology, 58, 3, 307-321. https://doi.org/10.1002/jclp.10020

Roy, D., Tripathy, S., Kar, S. K., Sharma, N., Verma, S. K., \& Kaushal, V. (2020). Study of knowledge, attitude, anxiety \& perceived mental healthcare need in Indian population during 


COVID-19 pandemic. Asian Journal of Psychiatry, 102083.
https://doi.org/10.1016/j.ajp.2020.102083

Rutter, M. (1987). Psychosocial resilience and protective mechanisms. American Journal of Orthopsychiatry, 57(3), 316-331. https://doi.org/10.1111/j.1939-0025.1987.tb03541.x

Saatç1, E. (2020). Üniversite ögrencilerinde mükemmeliyetçilik, belirsizliğe tahammülsüzlük ve psikolojik dayanıklılığın kendini engelleme üzerindeki etkisi [Yayınlanmamış Yüksek lisans tezi]. Fatih Sultan Mehmet Vakıf Üniversitesi Lisansüstü Eğitim Enstitüsü.

Sarıçam, H., Erguvan, F. M., Akın, A., \& Akça, M. Ş. (2014). Belirsizliğe Tahammülsüzlük Ölçeği (BTÖ-12) Türkçe Formu: Geçerlik ve güvenirlik çalışması. Route Educational and Social Science Journal, 1(3), 148-157.

Sari, S., \& Dağ, İ. (2009). Belirsizliğe Tahammülsüzlük Ölçeği, Endişe ile İlgili Olumlu İnançlar Ölçeği ve Endişenin Sonuçları Ölçeği'nin Türkçeye uyarlanması, geçerliliği ve güvenilirliği. Anadolu Psikiyatri Dergisi, 10, 270.

Satici, B., Gocet-Tekin, E., Deniz, M. E., \& Satici, S. A. (2020). Adaptation of the Fear of COVID19 Scale: Its association with psychological distress and life satisfaction in Turkey. International Journal of Mental Health and Addiction, 1. https://doi.org/10.1007/s11469-020-00294-0

Shanafelt, T., Ripp, J., \& Trockel, M. (2020). Understanding and addressing sources of anxiety among health care professionals during the COVID-19 pandemic. Jama, 323(21), 21332134. doi:10.1001/jama.2020.5893

Shaw, A., Joseph, S., \& Linley, P. A. (2005). Religion, spirituality, and posttraumatic growth: A systematic review. Mental Health, Religion \& Culture, 8(1), 1-11. https://doi.org/10.1080/1367467032000157981

Shevlin, M., McBride, O., Murphy, J., Miller, J. G., Hartman, T. K., Levita, L., ... \& Bennett, K. M. (2020). Anxiety, Depression, Traumatic Stress, and COVID-19 Related Anxiety in the UK General Population During the COVID-19 Pandemic. https://psyarxiv.com/hb6nq/download/?format=pdf

Soraci, P., Ferrari, A., Abbiati, F. A., Del Fante, E., De Pace, R., Urso, A., \& Griffiths, M. D. (2020). Validation and psychometric evaluation of the Italian version of the Fear of COVID-19 Scale. International Journal of Mental Health and Addiction, 1-10. https://doi.org/10.1007/s11469-020-00277-1

Steinhardt, M. \& Dolbier, C. (2008). Evaluation of a resilience intervention to enhance coping strategies and protective factors and decrease symptomatology. Journal of American College Health, 56(4), 445-453. https://doi.org/10.3200/JACH.56.44.445-454

Stewart, M., Reid, G. J., \& Mangham, C. (1997). Fostering children's resilience. Journal of Pediatric Nursing, 12 (1), 21-31. https://doi.org/10.1016/S0882-5963(97)80018-8

Şimşek, Ö. F. (2007). Yapisal eşitlik modellemesine giriş:(temel ilkeler ve LISREL uygulamalarl). Ekinoks.

Talidong, K. J. B., \& Toquero, C. M. D. (2020). Philippine teachers' practices to deal with anxiety amid COVID-19. Journal of Loss and Trauma, 1-7. https://doi.org/10.1080/15325024.2020.1759225

Tan, B. Y., Chew, N. W., Lee, G. K., Jing, M., Goh, Y., Yeo, L. L., ... \& Shanmugam, G. N. (2020). Psychological impact of the COVID-19 pandemic on health care workers in Singapore. Annals of Internal Medicine. https://doi.org/10.7326/M20-1083 
Tantan Ulu, Ş. (2019). Kaygı, karar verme ve belirsizliğe tahammülsüzlük arasındaki ilişkilerin incelenmesi [Yayınlanmamış yüksek lisans tezi]. Ege Üniversitesi Sosyal Bilimler Enstitüsü.

T. C. Sağlık Bakanlığı. (2020). COVID-19 (Yeni Koronavirüs Hastalı̆̆ https://covid19bilgi.saglik.gov.tr/tr/covid-19-yeni-koronavirus-hastaligi-nedir

T. C. Sağlık Bakanlığı. (2020). "Dışarı Çıkmayalım, Virüse Fırsat Tanımayalım”. https://www.saglik.gov.tr/TR,64846/bakan-koca-disari-cikmayalim-viruse-firsattanimayalim.html

Terzi, Ş. (2006). Kendini Toparlama Gücü Ölçeği’nin uyarlanması: Geçerlik ve güvenirlik çalışmaları. Türk Psikolojik Danışma ve Rehberlik Dergisi, 26(3), 77-86.

Tompkins, E., \& Adger, W. N. (2004). Does adaptive management of natural resources enhance resilience to climate change? Ecology and society, 9(2), 1-14. http://www.ecologyandsociety.org/vol9/iss2/art10

Wang, C., Pan, R., Wan, X., Tan, Y., Xu, L., Ho, C. S., \& Ho, R. C. (2020). Immediate psychological responses and associated factors during the initial stage of the 2019 coronavirus disease (COVID-19) epidemic among the general population in China. International Journal of Environmental Research and Public Health, 17(5), 1729. https://doi.org/10.3390/ijerph17051729

Wang, C., Horby, P. W., Hayden, F. G., \& Gao, G. F. (2020). A novel coronavirus outbreak of global health concern. The Lancet, 395(10223), 470-473. https://doi.org/10.1016/S01406736(20)30185-9

Yalım, D. (2007). Üniversite birinci sınıf öğrencilerinin uyumu: Psikolojik să̆lamlık, başa çıkma, iyimserlik ve cinsiyetin rolü [Yayımlanmamış yüksek lisans tezi]. Orta Doğu Teknik Üniversitesi.

Yang, Y., Li, W., Zhang, Q., Zhang, L., Cheung, T., Xiang, Y.T. (2020). Mental health services for older adults in China during the COVID-19 outbreak. The lancet Psychiatry, (20)30079-1. https://doi.org/10.1016/S2215-0366(20)30079-1

Zhang, W. R., Wang, K., Yin, L., Zhao, W. F., Xue, Q., Peng, M., ... \& Chang, H. (2020). Mental health and psychosocial problems of medical health workers during the COVID-19 epidemic in China. Psychotherapy and psychosomatics, 89(4), 242-250. https://doi.org/10.1159/000507639 